\title{
Seismicity and Active Compressional Tectonics in Santa Monica Bay, Southern California
}

\author{
EGILL HAUKSSON AND GEOFFREY V. SALDIVAR
}

Department of Geological Sciences, University of Southern California, Los Angeles

\begin{abstract}
During 1973-1986 the seismicity in Santa Monica Bay consisted of an average of four events per year of $M_{L} \geq 2.5$, in addition to the 1979 Malibu $\left(M_{L}=5.0\right)$ mainshock-aftershock sequence. The 1979 sequence ruptured a north dipping thrust fault at 10-15 km depth beneath the bay. A diffuse distribution of seismicity extends across the bay from the terminus of the Palos Verdes fault to Point Dume. Two thirds of the single-event focal mechanisms of 36 events that are located within the bay show mostly thrust or reverse faulting on west to westnorthwest striking planes. A third of the focal mechanisms exhibit strike-slip faulting on north to north-northwest striking planes. A stress inversion of the focal mechanism data shows that the maximum principal stress is oriented $N 13^{\circ} \mathrm{E}$ in a horizontal plane and the minimum principal stress is oriented $N 102^{\circ} \mathrm{E}$ and plunging $47^{\circ}$. Hence the tectonics in Santa Monica Bay are dominated by compression, with thrust, reverse, and strike-slip faulting. The coexistence of thrust and strike-slip faults suggests that the bay is not a part of the Peninsular Ranges terrane but forms a transition zone that accommodates the change from strike-slip in the Peninsular Ranges to the south to reverse faulting in the Transverse Ranges to the north. Mapped anticlines and the previously unrecognized thrust faults beneath the bay form two fold and thrust belts that present additional seismic hazards to Los Angeles and the southern Califomia coastal zone through seismic shaking and possible generation of small tsunamis.
\end{abstract}

\section{INTRODUCTION}

A portion of the boundary between two of southern California's tectonic provinces, the Peninsular Ranges and the Transverse Ranges, is located in Santa Monica Bay to the west of Los Angeles, southern California. Santa Monica Bay extends from the area north of Palos Verdes Peninsula to the Malibu coast line and from Santa Monica in the east to Point Dume in the west (Figure $1 a)$. The boundary separates the compressional tectonics of the Transverse Ranges from the strike-slip tectonics of the Peninsular Ranges [Yerkes, 1985]. The purpose of this study is to analyze the seismicity at this boundary in Santa Monica Bay to determine how the transition from strike-slip to reverse faulting is accommodated. The bay is well suited for studying this transition in detail, because the results of geological and geophysical surveys are available and the rate of seismicity is high compared to other regions west of the San Andreas fault.

The present tectonic interpretations of Santa Monica Bay are mostly derived from analysis of data collected during regional geological and geophysical surveys conducted by the U.S. Geological Survey and other groups during the late 1960s and 1970s [e.g., Vedder et al., 1974; Ziony et al., 1974; Junger and Wagner, 1977; Nardin and Henyey, 1978]. Structural interpretations and mapping of fault traces in the bay are based primarily on bathymetry and seismic reflection profiles with shallow penetration. These interpretations show that two major fault systems merge in Santa Monica Bay (Figure 1a). The Anacapa-Dume and Santa Monica faults, the southern

Copyright 1989 by the American Geophysical Union.

Paper number 89JB00110.

0148-0227/89/89JB-00110\$05.00 edge of the Transverse Range frontal system, strike west along the northern edge of the bay and are characterized by predominantly reverse faulting. The other major fault system within the bay is the northwest striking Palos Verdes fault, characterized by mostly right-lateral strikeslip faulting. Previous interpretations show the bay as a part of the Peninsular Ranges with these faults either merging or terminating against each other in the northern bay [e.g. Clarke et al., 1985].

From 1973 to 1986 the moderate level of seismicity in Santa Monica Bay consisted of frequent single shocks of $M_{L} \leq 4.0$ and the 1979 Malibu mainshock-aftershock sequence. The $M_{L}=5.01979$ Malibu mainshock occurred on January 1,1979, and was followed by an extensive aftershock sequence. The focal mechanisms of the mainshock and the aftershock hypocenters indicate that this earthquake occurred on a thrust or reverse fault similar to the 1987 Whittier Narrows earthquake [Hauksson and Saldivar, 1986; Saldivar, 1987].

The 1987 Whittier Narrows $\left(M_{L}=5.9\right)$ earthquake occurred $60 \mathrm{~km}$ to the east of Santa Monica Bay and ruptured a thrust fault between depths of 11 and $16 \mathrm{~km}$ [Hauksson et al., 1988; Hauksson and Jones, this issue]. It was also located $5-10 \mathrm{~km}$ to the south of the Raymond Hill fault which had been mapped before the earthquake as the southernmost reverse fault of the Transverse Ranges in the northeast Los Angeles basin. The focal mechanism [Hauksson and Jones, this issue] and geological interpretation of the Whittier Narrows earthquake by Davis et al. [this issue] suggest that a 10 to $15 \mathrm{~km}$ wide transition zone of west striking blind thrust faults plays a major role in accommodating the change from strike-slip to reverse faulting in the northern Los Angeles basin.

The existence of thrust or reverse faults along the northern flank of the Los Angeles basin and in Santa Monica Bay has important implications for estimates of 

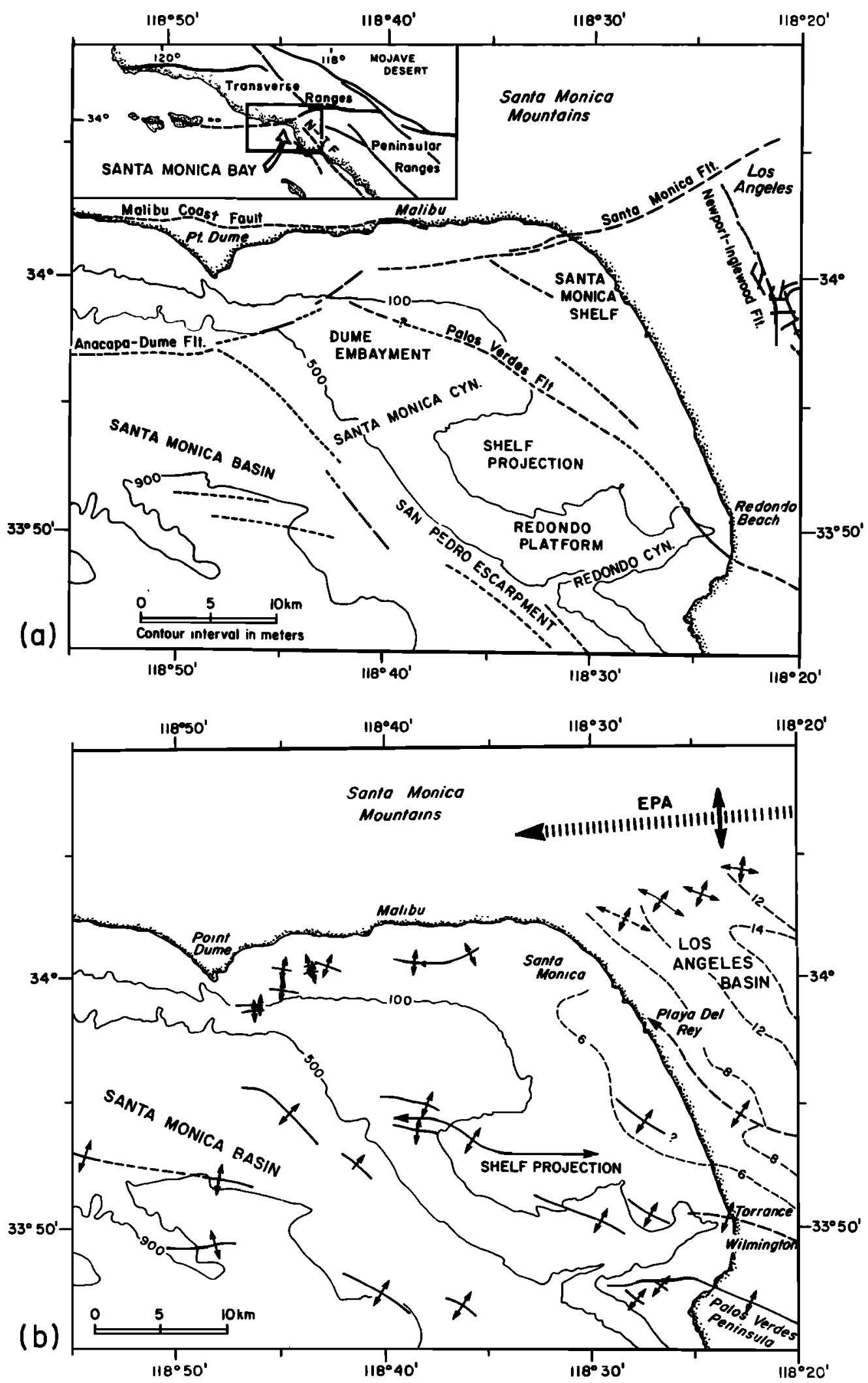

Fig. 1. (a) Fault map of study area in Santa Monica Bay showing major faults. (Inset) Location of study area is near the western edge of the intersection between the Transverse Ranges and Peninsular Ranges in southern Califormia. Location of faults is from Junger and Wagner [1977], where long dashed lines are reliably inferred faults and short dashed lines are less reliably inferred faults. (b) Map of Santa Monica Bay showing mapped anticlinal axes from Yerkes, et al. [1965], Junger and Wagner [1977], Nardin [1976], Nardin and Henyey [1978], and Harding and Tuminas [1988]. Solid lines with double arrows indicate axes of mapped anticlinal structures. EPA, the axis of the Elysian Park antiform from Davis et al. [this issue]. Depth to basement contours (dashed lines) in units of $\times 1000 \mathrm{ft}$ for the Los Angeles basin are shown to the right [Yerkes et al., 1965]. Bathymetric contours in the bay are in meters and are shown as solid lines. 
seismic hazards in the greater Los Angeles metropolitan area. It increases the likelihood of more frequent damaging ground shaking because previously unrecognized potential sources are located beneath or adjacent to the metropolitan area. In the bay, small tsunamis could also be generated by thrust faulting events, both as a result of uplift of the seafloor and local slumping of sediments [McCulloch, 1985]. The existence of thrust or reverse faults also increases the number of seismogenic faults that must be included in estimates of seismic hazards. Although most of these faults have low geologic slip rates (less than $1 \mathrm{~mm} / \mathrm{yr}$ ), the convergence rate over the greater Los Angeles basin may be as large as $5.6-13.6 \mathrm{~mm} / \mathrm{yr}$ [Davis et al., this issue].

\section{Tectonic Setting}

The Santa Monica Bay is located within the Peninsular Ranges province and is flanked on the east by the Los Angeles basin, on the west by the Santa Monica basin, on the south by the Palos Verdes Peninsula, and on the north by the Santa Monica mountains. The continental shelf forms the shallow part of the bay and extends from Point Dume to Palos Verdes, with a projection of the Santa Monica shelf to the west in the center of the bay. The Dume embayment is located between the shelf projection and Point Dume, and forms a gentle slope extending into the Santa Monica basin. Except for the Dume embayment, the western part of the bay slopes steeply into the Santa Monica basin. The northern bay is separated from the mountains by west striking reverse faults such as the Anacapa-Dume, Malibu coast, and Santa Monica faults (Figure 1a). From the south the northwest striking Palos Verdes fault enters the bay and exhibits mostly right-lateral strike-slip movement. It terminates against the Anacapa-Dume fault [e.g., Junger and Wagner, 1977; Clarke et al., 1985].

In addition to the reverse and strike-slip faulting, active folding is observed in Santa Monica Bay. In Figure $1 b$, fold axes from mapped anticlines in the bay are plotted [Yerkes et al., 1965; Nardin, 1976; Junger and Wagner, 1977; Nardin and Henyey, 1978; Harding and Tuminas, 1988]. The western flank of the Los Angeles basin consists of at least three major anticlines, the Palos Verdes, Torrance-Wilmington, and Playa Del Ray anticlines. Within the bay, two large ( the Santa Monica shelf projection and the Santa Monica basin anticlines) and numerous smaller anticlines have been mapped. The Torrance-Wilmington anticline and the Santa Monica shelf projection anticline form a trend striking westnorthwest across the southern part of the bay. Only several small anticlines are shown along the Malibu shelf, although Junger and Wagner [1977] indicate that the structural relief between the shelf and the Santa Monica basin was mostly formed through folding of the shelf. Hence the deformation of the bay appears to have been accommodated both through folding and faulting since late Miocene time.

In previous tectonic interpretations of the bay, the anticlines have been explained as secondary structures that result from wrench faulting on right-lateral strike slip faults [e.g. Campbell and Yerkes, 1976; Clarke et al., 1985]. Nardin and Henyey [1978] suggested a similar shear deformation model that included some fault normal compression to explain the development of the anticlines. The recent occurrences of moderate-sized or large earthquakes such as 1983 Coalinga and 1987 Whittier Narrows beneath and uplifting anticlinal structures, however, suggest that anticlines can be rooted in buried seismogenic thrust faults and may play a more important role in accommodating crustal deformation than previously thought [e.g., Lin and Stein, this issue]. One possible explanation could be that the buried thrust faults and associated anticlines form a transition zone of deformation between the strike-slip faults to the south and the reverse faults to the north. In this model the Palos Verdes fault may terminate south of the Anacapa-Dume fault. This model avoids the inconsistency in previous interpretations for the termination of the Palos Verdes fault against the Anacapa-Dume fault, which implied that the movement on the fault changes abruptly from rightlateral slip to left-lateral slip [Junger and Wagner, 1977].

\section{Data AND MeThods}

The study area covers Santa Monica Bay and extends from latitude $33^{\circ} 50^{\prime} \mathrm{N}$ to $34^{\circ} 8^{\prime} \mathrm{N}$ and from longitude $118^{\circ} 23^{\prime} \mathrm{W}$ to $118^{\circ} 50^{\prime} \mathrm{W}$ (Figure $2 a$ ). The northern limit of the study area is within the Santa Monica Mountains and was chosen to include earthquakes occurring near the Anacapa-Dume and Santa Monica faults.

The earthquake data set analyzed in this study consists of 61 events of $M_{L} \geq 2.5$ which occurred in Santa Monica Bay from 1973 to 1986 and are recorded by the California Institute of Technology/U.S. Geological Survey CIT/USGS) Southern California Seismic Network and the University of Southern California (USC) Los Angeles Basin Seismic Network. This data set included only the mainshock $\left(M_{L}=5.0\right)$ and largest aftershock $\left(M_{L}=4.2\right)$ of the 1979 Malibu sequence. In addition, a set of 412 earthquakes of $M_{L} \leq 2.5$ from 1981 to 1986 and 52 aftershocks of $M_{L} \geq 2.5$ from the 1979 Malibu sequence were relocated to gain further insight into the distribution of seismicity within the bay. This study complements the analysis by Hauksson and Saldivar [1986] of the 1979 Malibu sequence and by Hauksson [1987] of the seismicity of the Newport-Inglewood fault zone (see also Figure 2a).

The 61 events of $M_{L} \geq 2.5$ were reviewed to maximize the available number of first motions and to include all $P$ arrivals as well as $S$ arrivals. Phase cards were obtained from the CIT/USGS network for the period 1973 to 1976 and digital seismograms for the period 1977 to 1986. From the USC Los Angeles basin and Santa Barbara Channel seismic networks, analog paper records and phase cards were obtained for the period 1973 to 1983 and digital seismograms for the years 1984 to 1986 .

To obtain improved velocity models for the Santa Monica Bay region, the $P$ and $S$ arrival time data recorded at stations (Figure $2 b$ ) within $130 \mathrm{~km}$ distance of the center of the bay, and from the 61 events of $M_{L} \geq 2.5$ were inverted using the VELEST program [Roecker and Ellsworth, 1978]. No quarry blasts have been detonated within the study region to allow calibrations to be determined. The starting velocity models for VELEST, however, were the same as the models used by Hauksson 


\section{LOS ANGELES BASIN SEISMICITY 1973 - 1986}

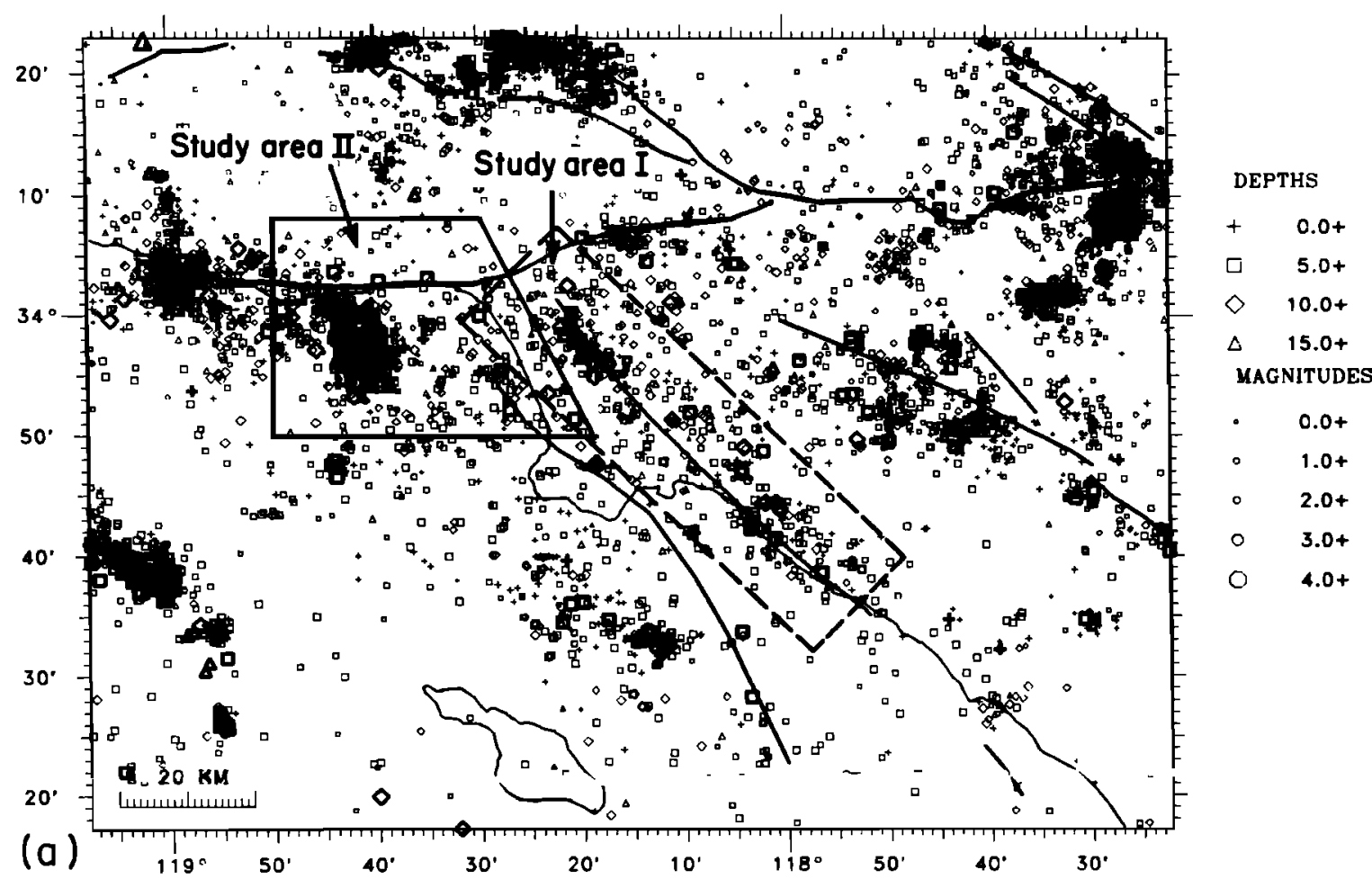

\section{SEISMOGRAPH STATIONS}

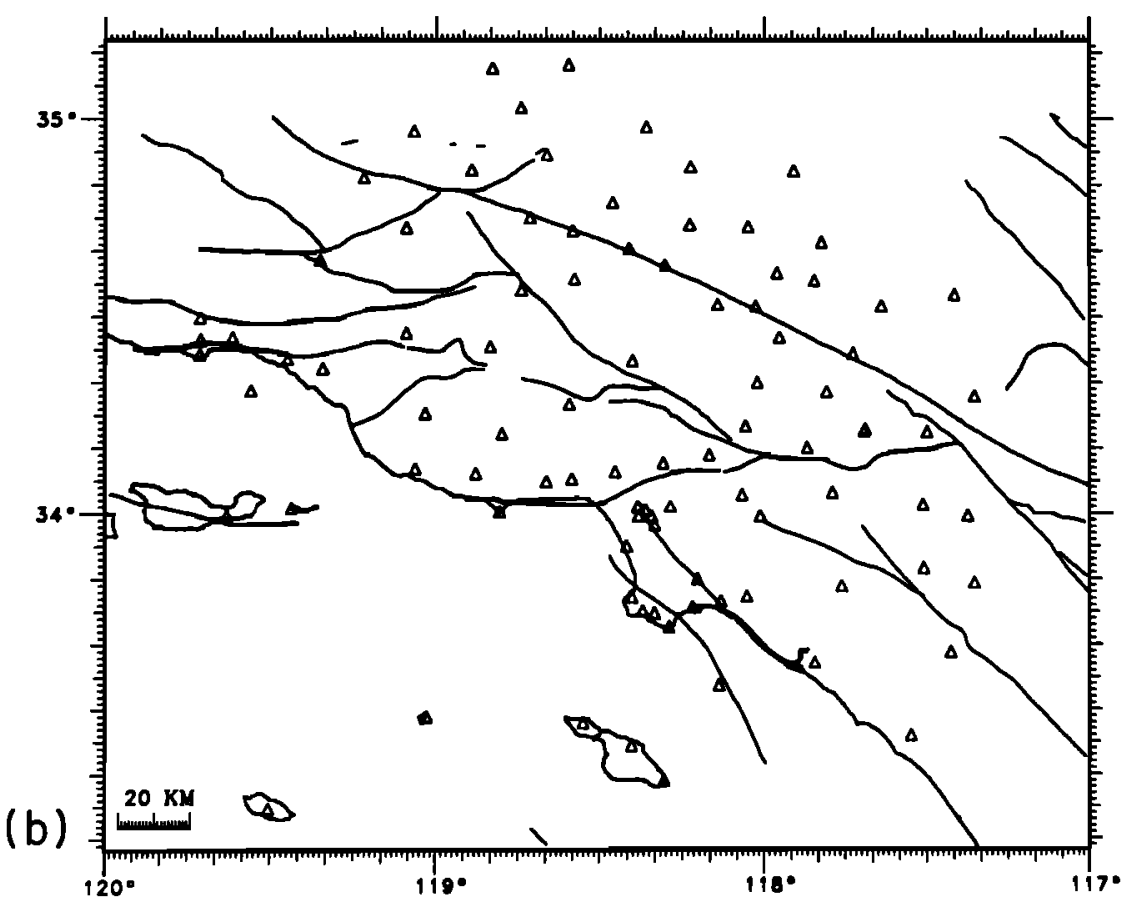

Fig. 2. (a) Seismicity reported from January 1973 to December 1986 by the CIT/USGS and USC seismic networks. Area boxed and labeled study zone II includes the seismicity analyzed in this study. The area labeled study zone I includes seismicity around the Newport-Inglewood fault analyzed by Hauksson [1987]. Symbol types and sizes indicate focal depth and catalog magnitude, respectively. (b) Map showing seismograph stations used in the VELEST inversion to relocate the hypocenters. 
and Jones [this issue] for the Whittier Narrows sequence that was constrained using arrival time data from a nearby blast. The final models (Table 1 ) and station delays are similar to the models obtained for the Whittier Narrows area [Hauksson and Jones, this issue]. These models and delays are preferred because they provide the smallest rootmean-square (Rms) travel time misfit and reduce the Rms from 0.35 to $0.17 \mathrm{~s}$ for the set of 61 earthquakes. In most cases the seismic stations along the coast provide adequate depth constraints, although shallow earthquakes located far from the coast have less well constrained focal depths than events located near the coast (Figure 2b). It is not possible to evaluate the absolute location accuracy, but the horizontal and depth uncertainties of the relative locations of the 61 events are less than $2 \mathrm{~km}$.

The HYPOINVERSE location program [Klein, 1985] was used to relocate the 525 earthquakes using the new velocity models and corresponding station delays. A cosine distance taper from 120 to $130 \mathrm{~km}$ was applied to each data set after four iterations, to minimize the effects of phases picked for more distant stations. A total of 261 events, from the set of 525 events, had horizontal and vertical errors less than $2 \mathrm{~km}$.

Lower hemisphere focal mechanisms of single events were determined for 36 of the 61 earthquakes $\left(M_{L} \geq 2.5\right)$. These 36 solutions were for earthquakes that occurred from 1977-1986 and had both CIT/USGS and USC station recordings available for examination and had no extensive interference from foreshocks. Polarities of reversed stations were corrected using information from Norris et al. [1986]. Takeoff angles were checked against reduced travel time curves generated for each event. The focal mechanisms that are shown in Figure 3 and listed in Table 2 were determined using a grid-searching algorithm and computer programs by Reasenberg and Oppenheimer [1985].

The 36 focal mechanisms were used to invert for the orientation of the principal stresses and a measure of their relative magnitude $(\emptyset)$, with a technique developed by

TABLE 1. $P$ Wave Velocity Models

\begin{tabular}{lcc}
\hline $\begin{array}{l}\text { Initial } \\
\text { Velocity, } \\
\mathrm{km} / \mathrm{s}\end{array}$ & $\begin{array}{l}\text { Refined } \\
\text { Velocity, } \\
\mathrm{km} / \mathrm{s}\end{array}$ & $\begin{array}{c}\text { Depth to Top } \\
\text { of Layer, } \\
\mathrm{km}\end{array}$ \\
\hline \multicolumn{3}{l}{ Southern Califomia Model } \\
5.50 & 4.04 & 0.00 \\
5.50 & 5.22 & 2.00 \\
6.30 & 6.18 & 5.50 \\
6.70 & 6.57 & 16.0 \\
7.80 & 7.80 & 32.0 \\
& & \\
3.30 & Santa Monica Bay Model \\
4.00 & 3.30 & 0.00 \\
5.90 & 4.14 & 2.00 \\
6.50 & 6.04 & 5.50 \\
6.70 & 6.25 & 13.0 \\
7.80 & 6.72 & 16.0 \\
\hline
\end{tabular}

Michael [1984]. The $\varnothing$ value is defined as $\varnothing=\left(S_{2}-S_{3}\right) /\left(S_{1}\right.$ $S_{3}$ ) where $S_{1}, S_{2}$, and $S_{3}$ are the maximum, intermediate, and minimum principal compressive stresses, respectively. The inversion technique assumes that the direction of shear stress on the fault plane is parallel to the observed slip direction on that plane determined from a focal mechanism. It also assumes that shear stress on each plane is similar in magnitude. For the inversion a nodal plane was chosen a priori from each focal mechanism as the actual fault plane. The north dipping planes from thrust mechanisms, the north to northwest striking planes from strike-slip mechanisms, and the east dipping plane from the one normal faulting mechanism were preferred. These planes are listed in Table 2 and are most consistent with mapped faults and other geological structures in the bay.

\section{RESULts}

\section{Seismicity (1973-1986)}

The seismicity in Santa Monica Bay during the last 14 years (from January 1973 to December 1986) consisted of the 1979 Malibu $\left(M_{L}=5.0\right)$ mainshock-aftershock sequence, and an average seismicity rate of four events of $M_{L} \geq 2.5$ occurring per year (Figure 4 ). This is similar to the rate of activity reported near the Newport-Inglewood fault [Hauksson, 1987]. This seismicity is related to the complex geologic structures in the bay including northnorthwest striking strike-slip faults and west striking reverse faults, as well as buried thrust faults beneath west to west-northwest trending anticlines.

In Figure $5 a$ the relocated seismicity in Santa Monica Bay and major faults mapped by Junger and Wagner [1977] are shown. These events have horizontal and vertical errors less than $2 \mathrm{~km}$ and represent approximately $60 \%$ of the reported seismicity. Although the seismicity in the bay is diffuse, several spatial clusters can be seen. The most prominent spatial clusters of seismicity are the 1979 Malibu sequence in the Dume embayment and several small spatial clusters of seismicity located near the eastward extension of the Anacapa-Dume fault. Some earthquake activity also occurred around the Santa Monica shelf projection and offshore from Redondo Beach, near the Palos Verdes fault. The northeastem comer of the bay and the Santa Monica Mountains, as well as the Malibu shelf to the north of the Santa Monica fault, are characterized by seismic quiesence.

The 1979 sequence is discussed in detail by Hauksson and Saldivar [1986]. It occurred in the Dume embayment (Figure 5a) and probably ruptured a west striking and north dipping thrust fault. Hauksson and Saldivar [1986] suggested that this sequence occurred near the eastern end of the Anacapa-Dume fault. Both the focal mechanism of the mainshock and the depth distribution of the sequence, which is mostly in the depth interval of $10-15 \mathrm{~km}$, however, could be interpreted as caused by rupture of a buried thrust fault, similar to the 1987 Whittier Narrows $\left(M_{L}=5.9\right)$ earthquake. This sequence, however, is not located directly beneath an anticlinal axis. Although the north dipping nodal plane of the mainshock focal mechanism projects up to the shelf projection anticline to the south, it is not possible to tell if these are causally related. 

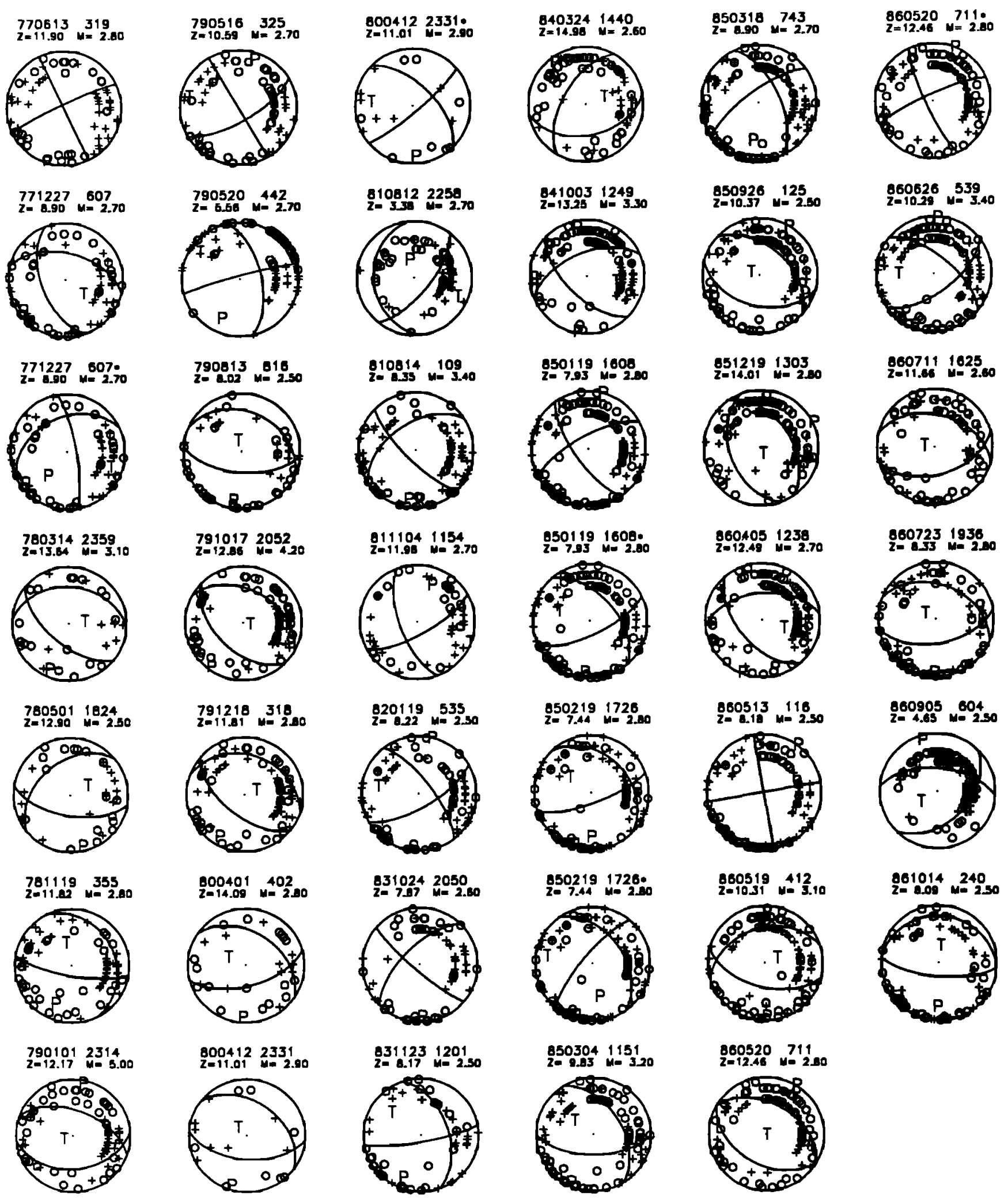

Fig. 3. Lower hemisphere (single-event) focal mechanisms for $36 M_{L} \geq 2.5$ Santa Monica Bay earthquakes. Pluses indicate dilatational first motion, and solid circles indicate compressional first motion. $P$ and $T$ axes are shown. Each mechanism is labeled with date and time of occurrence and focal depth in kilometers and local magnitude. Multiple solutions for each event are flagged by a star. Nodal planes were determined using the Reasenberg and Oppenheimer [1985] grid search algorithms. 
TABLE 2. Hypocenters and Focal Mechanisms of the 1977-1986 Seismicity in Santa Monica Bay

\begin{tabular}{|c|c|c|c|c|c|c|c|c|}
\hline \multirow{2}{*}{$\begin{array}{c}\text { Origin } \\
\text { Day }\end{array}$} & \multirow{2}{*}{$\begin{array}{c}\text { Time } \\
\text { UT }\end{array}$} & \multirow{2}{*}{$\begin{array}{c}\text { Latitude } \\
\mathbf{N}\end{array}$} & \multirow{2}{*}{ Longitude } & \multirow{2}{*}{$\begin{array}{c}\text { Depth, } \\
\text { km }\end{array}$} & \multirow{2}{*}{$\begin{array}{l}\text { Magnitude } \\
M_{L}\end{array}$} & \multicolumn{3}{|c|}{ Focal Mechanism } \\
\hline & & & & & & Ddir & Dip & Rake \\
\hline June 13,1977 & 0319 & $33^{\circ} 52.4^{\prime}$ & $118^{\circ} 37.3^{\prime}$ & 11.9 & 2.8 & $245^{\circ}$ & $90^{\circ}$ & $175^{\circ}$ \\
\hline Dec. 27,1977 & 0607 & $33^{\circ} 54.3^{\prime}$ & $118^{\circ} 32.8^{\prime}$ & 8.9 & 2.7 & $14^{\circ}$ & $51^{\circ}$ & $48^{\circ}$ \\
\hline March 14, 1978 & 2359 & $34^{\circ} 0.1^{\prime}$ & $118^{\circ} 40.4^{\prime}$ & 13.6 & 3.1 & $4^{\circ}$ & $36^{\circ}$ & $59^{\circ}$ \\
\hline May 1,1978 & 1824 & $33^{\circ} 56.8^{\prime}$ & $118^{\circ} 44.2^{\prime}$ & 12.9 & 2.5 & $321^{\circ}$ & $41^{\circ}$ & $49^{\circ}$ \\
\hline Nov. 19,1978 & 0355 & $34^{\circ} \quad 0.8^{\prime}$ & $118^{\circ} 37.7^{\prime}$ & 11.8 & 2.8 & $65^{\circ}$ & $25^{\circ}$ & $142^{\circ}$ \\
\hline Jan. 1,1979 & 2314 & $33^{\circ} 57.0^{\prime}$ & $118^{\circ} 40.3^{\prime}$ & 12.2 & 5.0 & $20^{\circ}$ & $53^{\circ}$ & $106^{\circ}$ \\
\hline May 16,1979 & 0325 & $33^{\circ} 51.0^{\prime}$ & $118^{\circ} 31.3^{\prime}$ & 10.6 & 2.7 & $60^{\circ}$ & $90^{\circ}$ & $160^{\circ}$ \\
\hline May 20, 1979 & 0442 & $33^{\circ} 51.2^{\prime}$ & $118^{\circ} 31.5^{\prime}$ & 5.6 & 2.7 & $78^{\circ}$ & $60^{\circ}$ & $-174^{\circ}$ \\
\hline Aug. 13, 1979 & 0816 & $33^{\circ} 54.8^{\prime}$ & $118^{\circ} 29.8^{\prime}$ & 8.0 & 2.5 & $24^{\circ}$ & $32^{\circ}$ & $107^{\circ}$ \\
\hline Oct. 17,1979 & 2052 & $33^{\circ} 55.8^{\prime}$ & $118^{\circ} 39.2^{\prime}$ & 12.9 & 4.2 & $31^{\circ}$ & $41^{\circ}$ & $78^{\circ}$ \\
\hline Dec. 18,1979 & 0318 & $33^{\circ} 56.7^{\prime}$ & $118^{\circ} 39.4^{\prime}$ & 11.8 & 2.8 & $21^{\circ}$ & $32^{\circ}$ & $73^{\circ}$ \\
\hline April 1,1980 & 0402 & $34^{\circ} 0.5^{\prime}$ & $118^{\circ} 39.7^{\prime}$ & 14.1 & 2.8 & $34^{\circ}$ & $41^{\circ}$ & $131^{\circ}$ \\
\hline April 12, 1980 & 2331 & $34^{\circ} \quad 3.1^{\prime}$ & $118^{\circ} 43.0^{\prime}$ & 11.0 & 2.9 & $37^{\circ}$ & $40^{\circ}$ & $116^{\circ}$ \\
\hline Aug. 12, 1981 & 2258 & $34^{\circ} \quad 7.5^{\prime}$ & $118^{\circ} 36.5^{\prime}$ & 3.4 & 2.7 & $265^{\circ}$ & $30^{\circ}$ & $-130^{\circ}$ \\
\hline Aug. 14, 1981 & 0109 & $33^{\circ} 57.8^{\prime}$ & $118^{\circ} 34.3^{\prime}$ & 8.3 & 3.4 & $225^{\circ}$ & $75^{\circ}$ & $140^{\circ}$ \\
\hline Nov. 4,1981 & 1154 & $33^{\circ} 54.5^{\prime}$ & $118^{\circ} 37.0^{\prime}$ & 12.0 & 2.7 & $250^{\circ}$ & $65^{\circ}$ & $-160^{\circ}$ \\
\hline Jan. 19,1982 & 0535 & $33^{\circ} 56.0^{\prime}$ & $118^{\circ} 28.7^{\prime}$ & 8.2 & 2.5 & $53^{\circ}$ & $71^{\circ}$ & $159^{\circ}$ \\
\hline Oct. 24,1983 & 2050 & $33^{\circ} 55.5^{\prime}$ & $118^{\circ} 28.6^{\prime}$ & 7.9 & 2.6 & $221^{\circ}$ & $81^{\circ}$ & $155^{\circ}$ \\
\hline Nov. 23,1983 & 1201 & $34^{\circ} \quad 1.8^{\prime}$ & $118^{\circ} 34.1^{\prime}$ & 8.2 & 2.5 & $72^{\circ}$ & $51^{\circ}$ & $167^{\circ}$ \\
\hline March 24, 1984 & 1440 & $34^{\circ} \quad 7.4^{\prime}$ & $118^{\circ} 32.7^{\prime}$ & 15.0 & 2.6 & $300^{\circ}$ & $57^{\circ}$ & $57^{\circ}$ \\
\hline Oct. 3,1984 & 1249 & $33^{\circ} 59.0^{\prime}$ & $118^{\circ} 39.2^{\prime}$ & 13.2 & 3.3 & $338^{\circ}$ & $56^{\circ}$ & $37^{\circ}$ \\
\hline Jan. 19,1985 & 1608 & $33^{\circ} 54.3^{\prime}$ & $118^{\circ} 28.3^{\prime}$ & 7.9 & 2.8 & $332^{\circ}$ & $71^{\circ}$ & $21^{\circ}$ \\
\hline Feb. 19, 1985 & 1726 & $33^{\circ} 53.8^{\prime}$ & $118^{\circ} 26.2^{\prime}$ & 7.4 & 2.8 & $46^{\circ}$ & $33^{\circ}$ & $152^{\circ}$ \\
\hline March 4, 1985 & 1151 & $33^{\circ} 59.6^{\prime}$ & $118^{\circ} 34.5^{\prime}$ & 9.8 & 3.2 & $59^{\circ}$ & $48^{\circ}$ & $138^{\circ}$ \\
\hline March 18, 1985 & 0743 & $33^{\circ} 59.4^{\prime}$ & $118^{\circ} 34.6^{\prime}$ & 8.9 & 2.7 & $65^{\circ}$ & $60^{\circ}$ & $-160^{\circ}$ \\
\hline Sep. 26, 1985 & 0125 & $33^{\circ} 56.6^{\prime}$ & $118^{\circ} 35.4^{\prime}$ & 10.4 & 2.5 & $42^{\circ}$ & $48^{\circ}$ & $109^{\circ}$ \\
\hline Dec. 19,1985 & 1303 & $34^{\circ} 2.2^{\prime}$ & $118^{\circ} 28.5^{\prime}$ & 14.0 & 2.8 & $56^{\circ}$ & $46^{\circ}$ & $80^{\circ}$ \\
\hline April 5, 1986 & 1238 & $33^{\circ} 59.5^{\prime}$ & $118^{\circ} 43.3^{\prime}$ & 12.5 & 2.7 & $354^{\circ}$ & $51^{\circ}$ & $48^{\circ}$ \\
\hline May 13,1986 & 0116 & $33^{\circ} 50.7^{\prime}$ & $118^{\circ} 34.3^{\prime}$ & 8.2 & 2.5 & $80^{\circ}$ & $90^{\circ}$ & $180^{\circ}$ \\
\hline May 19,1986 & 0412 & $33^{\circ} 53.5^{\prime}$ & $118^{\circ} 22.8^{\prime}$ & 10.3 & 3.1 & $343^{\circ}$ & $40^{\circ}$ & $64^{\circ}$ \\
\hline May 20, 1986 & 0711 & $33^{\circ} 56.4^{\prime}$ & $118^{\circ} 39.5^{\prime}$ & 12.5 & 2.8 & $30^{\circ}$ & $45^{\circ}$ & $90^{\circ}$ \\
\hline June 26,1986 & 0539 & $33^{\circ} 51.8^{\prime}$ & $118^{\circ} 26.3^{\prime}$ & 10.3 & 3.4 & $40^{\circ}$ & $65^{\circ}$ & $150^{\circ}$ \\
\hline July 11,1986 & 1625 & $33^{\circ} 59.5^{\prime}$ & $118^{\circ} 41.9^{\prime}$ & 11.7 & 2.6 & $15^{\circ}$ & $44^{\circ}$ & $112^{\circ}$ \\
\hline July 23, 1986 & 1936 & $33^{\circ} 51.2^{\prime}$ & $118^{\circ} 29.4^{\prime}$ & 8.3 & 2.8 & $22^{\circ}$ & $40^{\circ}$ & $116^{\circ}$ \\
\hline Sep. 5, 1986 & 0604 & $33^{\circ} 59.3^{\prime}$ & $118^{\circ} 32.9^{\prime}$ & 4.6 & 2.5 & $135^{\circ}$ & $45^{\circ}$ & $50^{\circ}$ \\
\hline Oct. 14,1986 & 0240 & $33^{\circ} 51.4^{\prime}$ & $118^{\circ} 33.7^{\prime}$ & 8.1 & 2.5 & $5^{\circ}$ & $20^{\circ}$ & $90^{\circ}$ \\
\hline
\end{tabular}

Figure $5 b$ is a north-northwest cross section of the seismicity in the northern bay near the Anacapa-Dume and Santa Monica faults. Most of the seismicity appears to be located to the south of the reverse faults, which are shown with a $60^{\circ}$ dip [Campbell and Yerkes, 1976]. This seismicity is mostly in the depth range of $9-16 \mathrm{~km}$. Figure $5 c$ is an east-northeast cross section of the Santa Monica Bay seismicity. This cross section that strikes almost normal to the Palos Verdes fault shows that in general the base of the seismicity is somewhat shallower immediately to the west than to the east of the fault.

The seismicity in the bay and the axes of mapped anticlinal structures are plotted in Figure $6 a$. In general the anticlinal axes form two distributions. The first extends along the northern flank of the Los Angeles basin into the northern part of Santa Monica Bay and appears to be associated with a spatial cluster of seismicity. The second is a continuation of the Torrance-Wilmington anticline and strikes west-northwest across the bay. A broad distribution of seismicity and possibly the 1979 sequence are associated with this fold and thrust belt. The north-northeast cross section in Figure $6 b$ shows the 1979 sequence and a scattered distribution of activity over the depth range from 0 to $16 \mathrm{~km}$. Although the events in the depth range $0-8 \mathrm{~km}$ have less well constrained focal depths, these could be secondary earthquake activity associated with folding of the shallow crust. Most of the events however, are located in the depth range $8-16 \mathrm{~km}$, which is consistent with active faulting at depth below the anticlines.

\section{Focal Mechanisms (1977-1986)}

In Figure 7 the axes of mapped anticlines, the major faults, and the 36 single-event lower hemisphere focal mechanisms are plotted at their respective epicentral location. These events that occurred from 1977 to 1986 are plotted with symbol size scaled according to magnitude. Two thirds of the events show mostly reverse or thrust faulting. The remaining events show mostly right-lateral strike-slip motion.

Thrust or reverse mechanisms are found throughout the bay to the south of the mapped reverse faults, the Anacapa-Dume and Santa Monica faults. Only one reverse faulting event is located to the north of the surface traces of these faults, and hence could be associated with these major reverse faults (Figure 7). The reverse or 


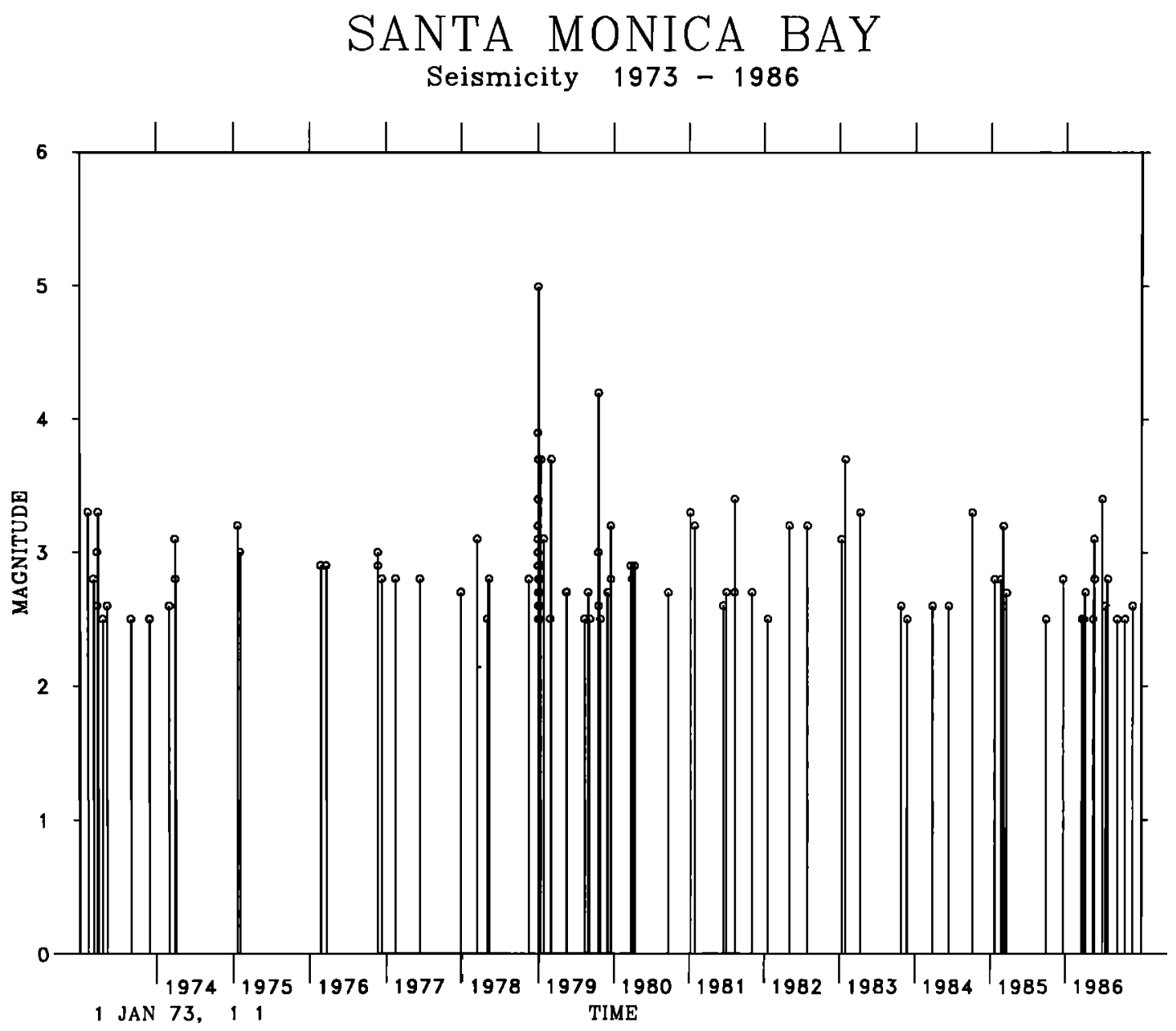

Fig. 4. A bar graph of magnitude versus time of $M_{L} \geq 2.5$ seismicity reported in the CIT/USGS catalog from January 1973 through December 1986, contained within the boxed area shown in Figure $2 a$.

thrust faulting events that are located within the bay have mostly west to west-northwest striking nodal planes with dips ranging from subhorizontal to almost vertical. Most of these thrust faulting events cluster in a limited depth range between 8 and $16 \mathrm{~km}$. The predominance of thrust and reverse faulting events throughout the bay suggests that slip on west to west-northwest striking thrust or reverse faults at depth beneath the bay plays an important role and should be included in tectonic interpretations of the bay.

Most of the strike-slip events are located near the southern and western edges of the Santa Monica shelf projection and offshore from Redondo Beach, near the Palos Verdes fault. Two strike-slip events occurred in the northeastern bay. The strike-slip events in the bay exhibit mostly right-lateral movement on steeply dipping and north to north-northwest striking nodal planes. The strike-slip events may indicate tear faulting on steeply dipping faults, which is secondary to the thrust faulting beneath the anticlines in the bay.

\section{State of Stress}

The results from inverting the focal mechanisms data for the orientations of the principal stress axes and a measure of their relative magnitude (ø) are shown in
Figure 8. The north dipping planes from the thrust focal mechanisms and the north to northwest striking planes were selected for the stress inversion. The orientations of the principal stress axes are not significantly influenced by the choice of planes but the confidence limits can be. The 95\% confidence limits that are shown in Figure 8 for the orientations of the stress axes were determined using bootstrap techniques assuming that $50 \%$ of the planes were picked incorrectly [Michael, 1987].

The maximum principal stress has an azimuth of $193^{\circ}$ and a plunge of $1^{\circ}$, while the intermediate and minimum principal stresses are oriented $284^{\circ}$, plunging $43^{\circ}$ and $102^{\circ}$ plunging $47^{\circ}$, respectively. The $\varnothing$ value is 0.1 , indicating that the intermediate stress is close in magnitude to the minimum stress. Hence the average stress state in Santa Monica Bay is similar to the stress state within the Transverse Ranges [Pechmann, 1987] and the state of stress in the northern Los Angeles basin [Hauksson, 1987].

\section{Discussion}

Seismicity, Faulting, and Folding

The spatial distribution of the major mapped faults and seismicity in Santa Monica Bay shows that the seismicity is not spatially clustered around these faults 


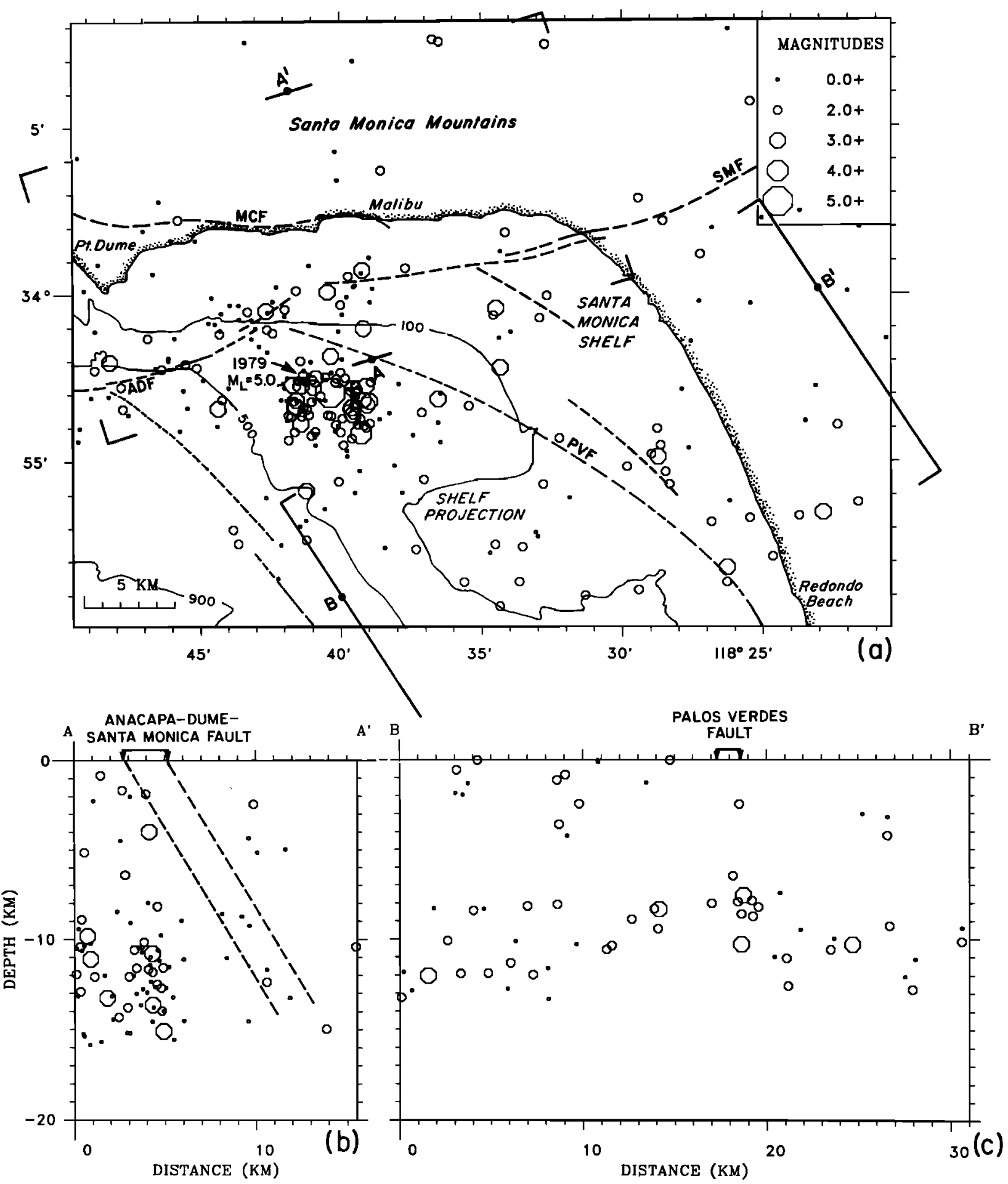

Fig. 5. (a) Relocated hypocenters for the 261 earthquakes with horizontal and vertical errors (erh and erz) less than $2.0 \mathrm{~km}$ recorded in Santa Monica Bay from 1973 to 1986. Offshore faults from Junger and Wagner [1977]. The $100-\mathrm{m}$ bathymetric contour defines the continental shelf break while the $500-\mathrm{m}$ depth contour defines the eastern edge of Santa Monica basin. MCF, Malibu coast fault; ADF, Anacapa-Dume fault; PVF, Palos Verdes fault; SMF, Santa Monica fault. (b) North-northwest cross section within the delineated box is projected along the line A-A'. The trace of the Santa Monica fault is shown bracketed by two lines because it projects into the cross section at an oblique angle. (c) East-northeast cross section within the delineated box is projected along the line B-B'. 


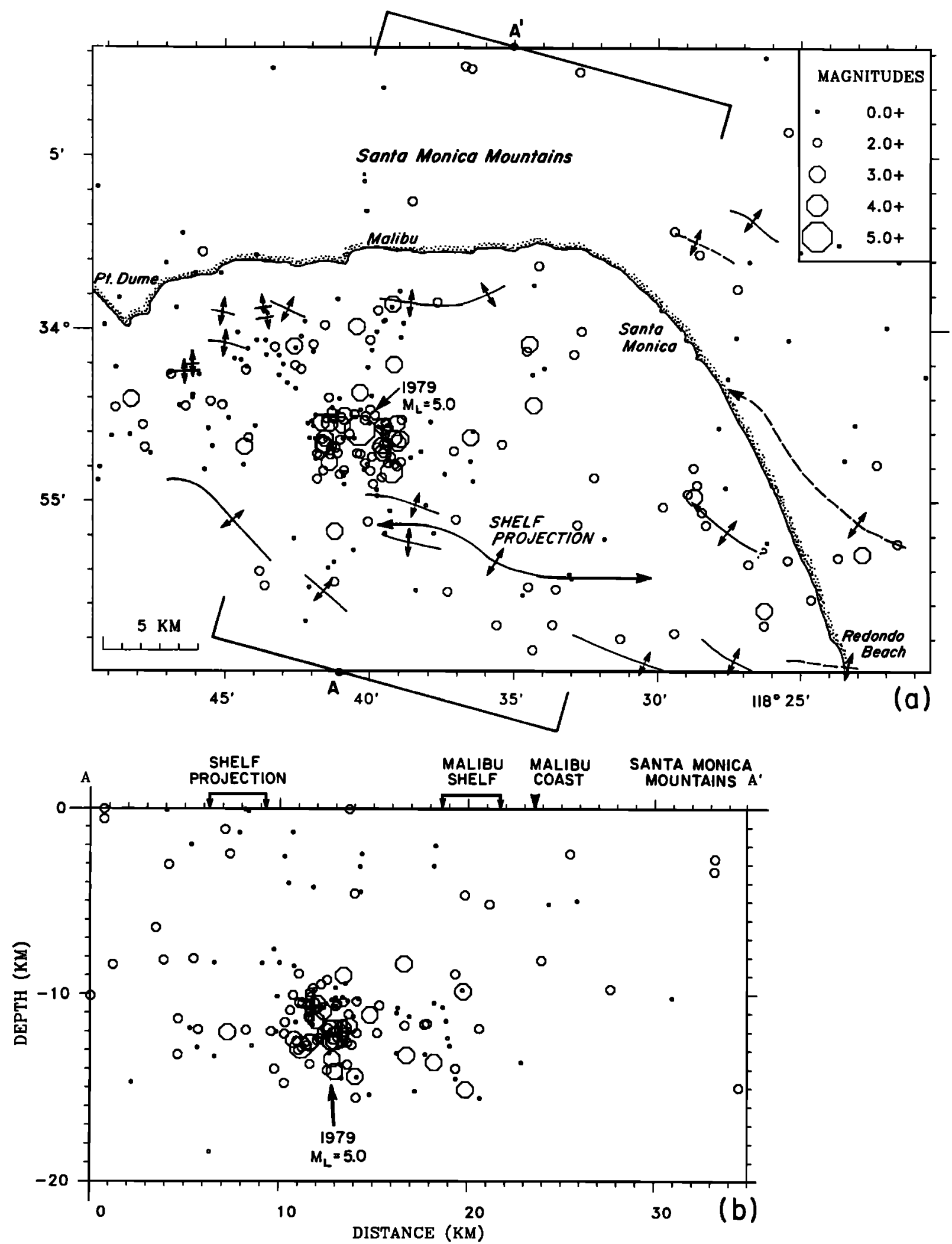

Fig. 6. (a) Relocated hypocenters for the 261 earthquakes with erh and erz less than $2.0 \mathrm{~km}$ recorded in Santa Monica Bay from 1973 to 1986 . Axes of anticlinal structures shown as heavy lines are the same as shown in Figure $1 b$. (b) North-northeast cross section within the delineated box is projected along the line A-A'. 


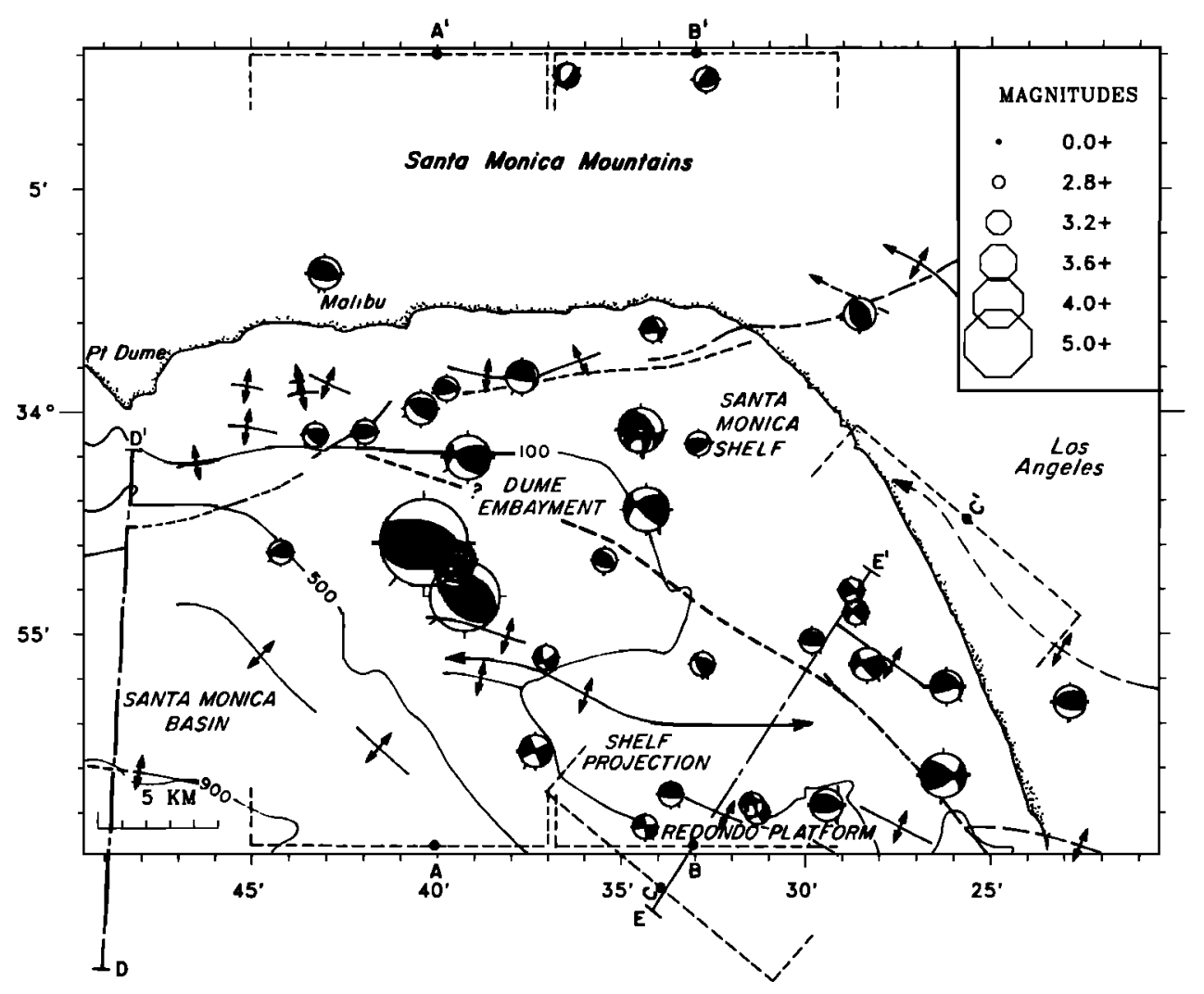

Fig. 7. Lower hemisphere (single-event) focal mechanisms for 36 earthquakes in Santa Monica Bay. The size of the mechanisms is scaled with the respective earthquake magnitude. An extra tick mark is added on the perimeter to each mechanisms to indicate depth, where $0-360^{\circ}$ corresponds to $0-20 \mathrm{~km}$ focal depth. Shaded areas are compressional quadrants. Cross sections shown in Figure 10 are indicated by A-A', B-B',C-C',D-D', and E-E'. Axes of anticlinal structures shown as heavy lines are from Figure $1 b$.

(Figure 5). The seismicity in the bay forms a diffuse distribution throughout the bay, which, except for the largest event in the data, is similar to the distribution of anticlines (Figure 6). The distribution of seismicity and the frequent occurrence of thrust or reverse and less frequent occurrence of strike-slip focal mechanisms suggest that the bay is not dominated by strike-slip faulting but rather is a transition zone between the strikeslip regime to the south and the reverse faulting regime to the north. The tectonic deformation in this transition zone is characterized by thrust faulting at depth and folding near the surface.

With the exception of the Malibu shelf the axes of anticlines in the bay have similar azimuthal orientations as the north dipping fault planes in the focal mechanisms (Figure 9). To illustrate further this relationship between the near-surface geologic structures mapped by Junger and Wagner [1977] and thrust faulting earthquakes, three cross sections of focal mechanisms and two shallow reflection profiles are shown in Figure 10. Although the Junger and Wagner section DD' is located near the western edge of the study zone, it is a representative north-south cross section of the geologic structures and thus can be tied in with the focal mechanisms. Both $\mathrm{AA}^{\prime}$ and $\mathrm{BB}^{\prime}$ show focal mechanisms in cross section and the respective compressional quadrants are shaded using the same conventions as in map view. In these cross sections a thrust faulting mechanism thus will look like a strike-slip event in map view.

In Figure 10 the south to north cross sections ( $\mathrm{AA}^{\prime}$ and $\mathrm{BB}^{\prime}$ ) of the focal mechanisms are shown with the reflection profile DD' from Junger and Wagner [1977]. The folding between the center of the basin and the Anacapa-Dume fault as seen in the reflection profile corresponds geometrically to the thrust mechanisms at depth. The thrust mechanisms thus indicate that the faults responsible for these folds are presently active. For reference the trace of the Santa Monica fault is projected with a dip of $60^{\circ}$ [Campbell and Yerkes, 1976] in the cross sections $\mathrm{AA}^{\prime}$ and $\mathrm{BB}^{\prime}$. The northeast trending cross section CC' $^{\prime}$ of focal mechanisms in Figure 10 is shown along with the reflection profile EE' from Junger and Wagner [1977]. In this case the occurrence of the thrust faulting events is consistent with the presence of the Santa Monica shelf projection, a large anticline, and the compressional fold structures located farther to the southwest beneath the basin sediments. The three focal mechanisms of strike-slip events to the right in the cross section CC" could be associated with the Palos Verdes fault. Presently, the Palos Verdes fault may contribute to the faulting in the bay as a tear fault and provide for an en echelon offset of the shelf projection to the north 


\section{SANTA MONICA BAY : STRESS STATE}

$50 \%$ OF FAULT PLANES ASSUMED PICKED CORRECTLY

a

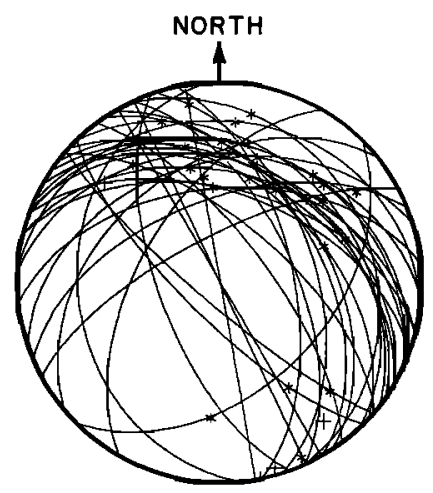

b

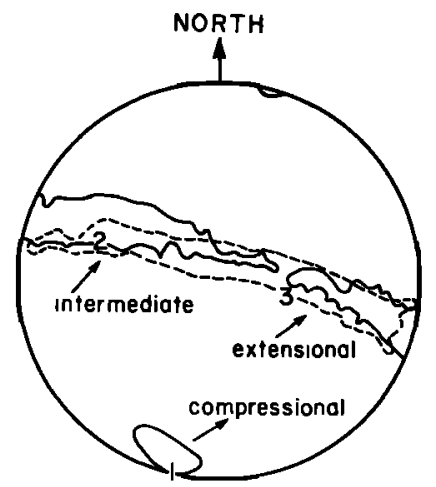

Fig. 8. Data and results from the stress inversion. (a) Lower hemisphere projection of all nodal planes with one from each focal mechanism. Location of the slip vector is shown on each nodal plane as a plus symbol (with a normal component) or a star (with a thrust component). (b) The orientations of the principal stress axis with $95 \%$ confidence areas, determined by assuming that $10 \%$ of the planes were picked incorrectly, indicated with solid or dashed lines; 1,2 , and 3 are maximum, intermediate, and minimum principal stress axes.

[Nardin and Henyey, 1978]. A similar tear fault may exist at the western edge of the shelf projection as suggested by the strike-slip mechanisms in Figure 7. These tear faults limit the spatial extent of the thrust fault beneath the shelf projection anticline.

The spatial coincidence of anticlines and thrust focal mechanisms in the bay suggests that at least two fold and thrust belts exist in the bay (Figure 11). The Santa Monica shelf projection appears to be a westward continuation of the Torrance-Wilmington anticlinorium. These structures thus may form a fold and thrust belt extending along the western flank of the Los Angeles basin into the Dume embayment. The continental shelf in the northern bay appears to consist of numerous anticlines, similar to the northern flank of the Los Angeles basin. These structures form the second fold and thrust belt extending from Whittier to Point Dume and possibly west to the northern Channel Islands. The existence of the Elysian Park and Torrance-Wilmington fold and thrust belts in the bay is also consistent with regional geologic interpretations by Davis et al. [this issue]. They suggested that the causative fault of the 1987 Whittier Narrows earthquake extends from Whittier, along the northern edge of the Los Angeles basin and the Santa Monica Bay, out to the northern Channel Islands.

\section{Earthquake Potential}

The results of analyzing the seismicity in Santa Monica Bay show that thrust or reverse faults exist at depth beneath the bay. The earthquake potential of these buried thrust faults, however, is difficult to evaluate in a quantitative way, because limited information is available on geologic slip rates and the poor constraints on the size of these faults. Furthermore, the lack of activity along the Anacapa-Dume and Santa Monica faults makes it impossible to evaluate their seismogenic capability.

The main results from this study show two fold and thrust belts that may be associated with the blind thrust faults beneath the bay. As shown in Figure 11, each of these two fault belts is at least $40 \mathrm{~km}$ long. The Torrance-Wilmington fold and thrust belt, however, may be segmented by right-lateral strike-slip faults, such as the Palos Verdes fault and a fault at the western edge of the shelf projection, striking north-northwest may cause enechelon offset and serve as tear faults [Nardin and Henyey, 1978].

If the geologic slip rates derived for the Elysian Park and the Torrance-Wilmington fold and thrust belts by Davis et al. [this issue] are assumed to apply to the faults beneath the bay, the slip rates on these faults are in the range 2.4-5.1 and 1.9-3.4 mm/yr, respectively. The two fold and thrust belts have a total length of approximately $80 \mathrm{~km}$. The geologic slip rates could result in many earthquakes of comparable size as the Whittier Narrows event, each with a rupture length of $5 \mathrm{~km}$ and repeat times of approximately 10-46 years, when using a coseismic slip of 0.8-1.4 $\mathrm{m}$ [Lin and Stein, this issue]. Alternately, these fault segments could rupture in earthquakes of comparable size as the San Fernando event, each with a rupture length of $20 \mathrm{~km}$ and with repeat times of approximately 73-329 years, using a coseismic slip of 1.5-2.5 m [Heaton, 1982]. These repeat times assume that most of the geological slip is accommodated by earthquakes rather than aseismic deformation.

The occurrence of a $M_{L}>6.5$ earthquake in Santa Monica Bay would cause strong ground shaking in Los Angeles and along the southern Califomia coastal zone [e.g., Ziony and Yerkes, 1985]. In addition, such an event may cause a small tsunami that could cause significant damage in coastal communities. The 1812 $(M=7-7.5)$ Santa Barbara and the $1927\left(M_{S}=7.3\right)$ Point Arguello earthquakes occurred in very similar compressive tectonic environments as exist in the bay. Both events generated damaging tsunamis [McCulloch, 1985]. The possibility of damaging tsunamis is also consistent with the mapped sediment failures in the bay [Clarke et al., 1985]. 


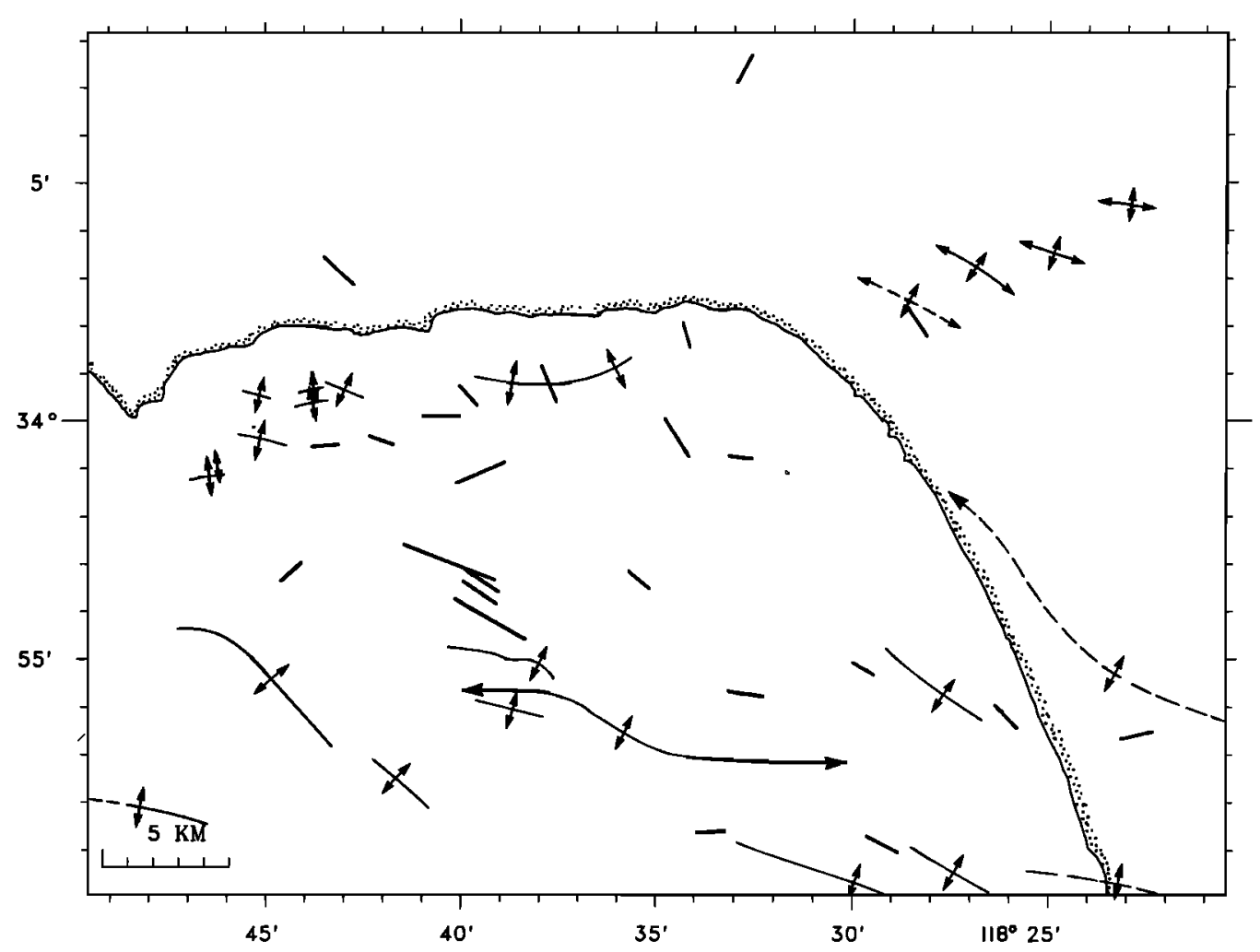

Fig. 9. Axes of anticlinal structures shown as lines with arrows are the same as in Figure $1 b$. The short heavy line segments represent the strike of the north dipping fault plane from each of the thrust or reverse faulting focal mechanisms in Figure 7.

\section{Active Tectonics}

The dominance of thrust faulting earthquakes in Santa Monica Bay is consistent with its youthful compressional geologic structures. The Malibu shelf and the Santa Monica shelf projection are two major anticlinal west and west-northwest striking structures that have at least $1000 \mathrm{~m}$ of topographic relief above the basin sediments [Junger and Wagner, 1977; Nardin and Henyey, 1978]. To accomplish this uplift, either significant aseismic deformation or seismic slip on blind thrust faults is needed. On the basis of the short seismicity record analyzed here, it is not possible to tell which of the two mechanisms of crustal deformation is more important.

Many interpretations of seismogenic structures that are related to compressional tectonics of the Transverse Ranges [Hadley and Kanamori, 1978; Webb and Kanamori, 1985; Namson and Davis, 1988] suggest the presence of a subhorizontal detachment surface at the base of the brittle-elastic crust. The presence of the two fold and thrust belts in the bay also suggests that a regional detachment may be present. The blind thrust faults that caused the 1979 Malibu and the 1987 Whittier Narrows earthquakes may be rooted in the detachment at depth and extend up into the brittle crust. Although the presence of a detachment is not required, it provides a framework for understanding the coexistence of the mapped compressional geological structures, the thrust faulting earthquakes, and a subducted slab beneath the Transverse Ranges.

The compressional tectonics and associated shortening of the upper crust in Santa Monica Bay may be caused by subduction of the lower crust and lithosphere beneath the Transverse Ranges. Humphreys et al. [1984] image a thin, east-west trending, almost vertical slab of steep north dipping higher-velocity material directly beneath the Transverse Ranges based on inversion of teleseismic $P$ delays. Part of this slab is to the north of Santa Monica Bay, beneath the western Santa Monica Mountains. Sheffels and McNutt [1986] also model this wedge with gravity measurements in three one-dimensional crosssections. Similarly, in a study of the kinematics of southern California, Bird and Rosenstock [1984] also provided evidence for subduction down to at least $250 \mathrm{~km}$ depth beneath the Transverse Ranges. The ongoing subduction causes crustal deformation and associated seismicity along the southern margin of the Transverse Ranges. The rate of seismicity in Santa Monica Bay is high compared to the rate of seismicity beneath the Santa Monica Mountains. This concentration of the seismicity in Santa Monica Bay may result from a thinner crust beneath the bay than beneath the mountains. Alternatively, the Santa Monica Mountains crustal block may be more rigid [Kamerling and Luyendyk, 1979] and cannot be deformed as easily as the already fragmented crust beneath the bay. 

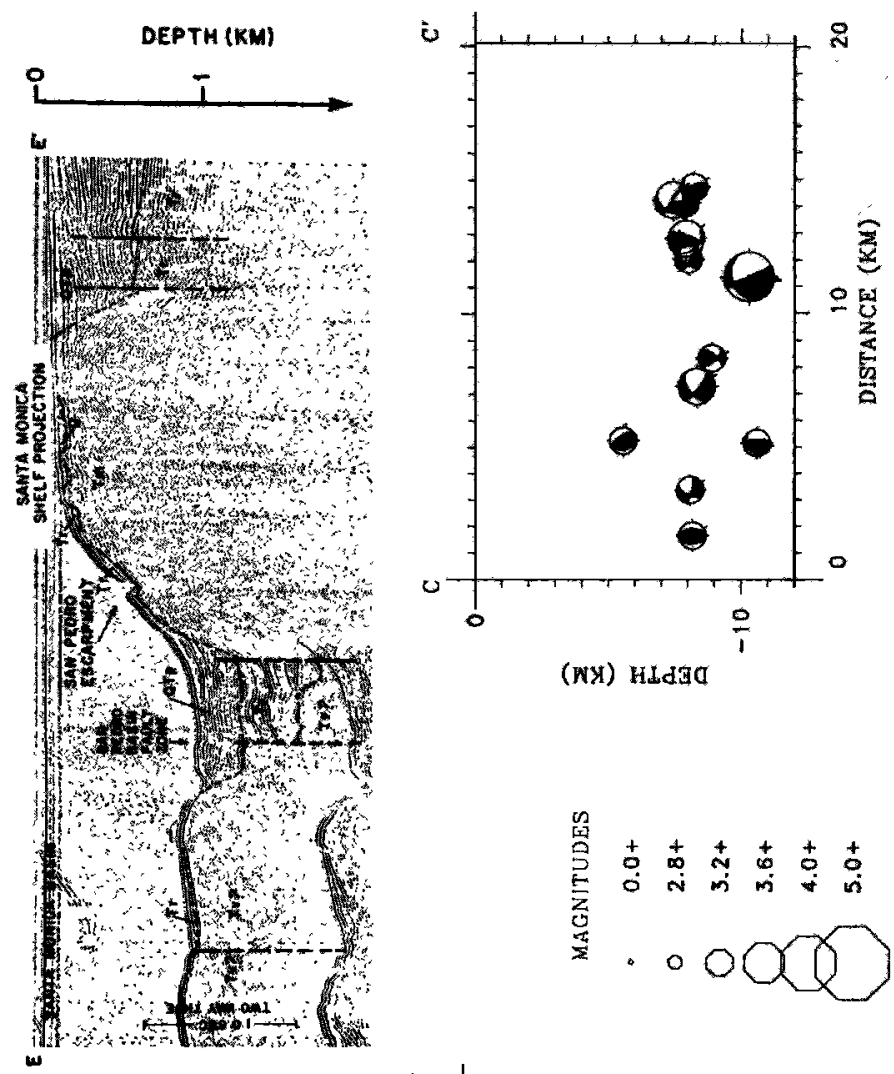

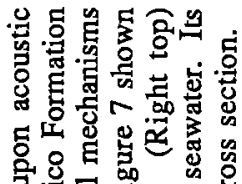

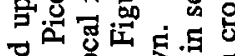

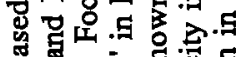

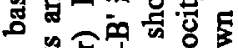

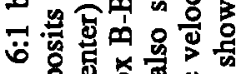

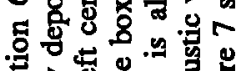

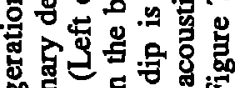
要

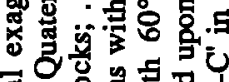

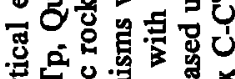

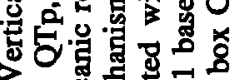

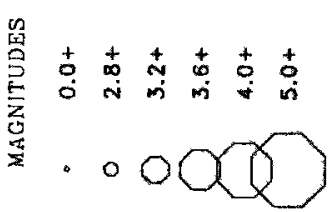

$>$ 害웡

官迢”

월영

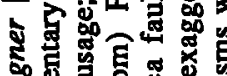

S

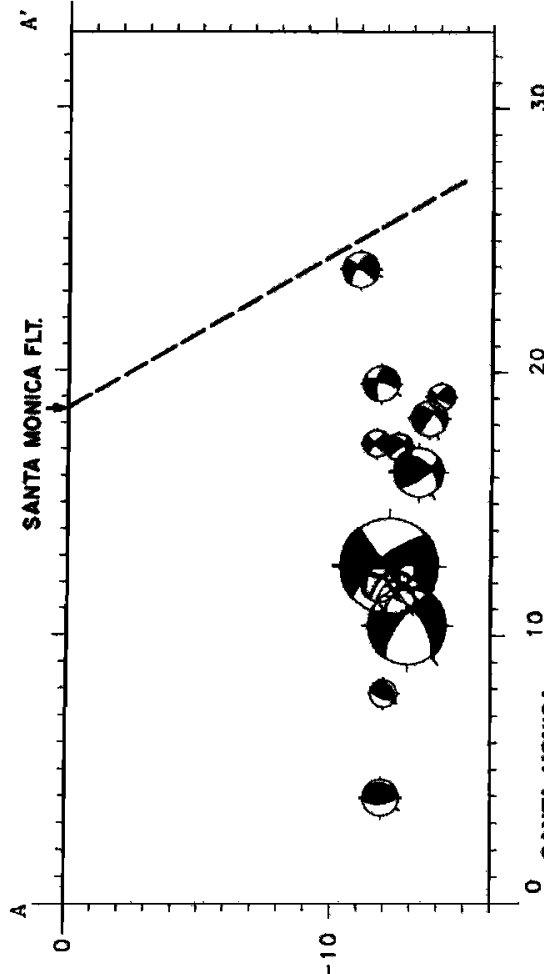

(ผX) HLdGa

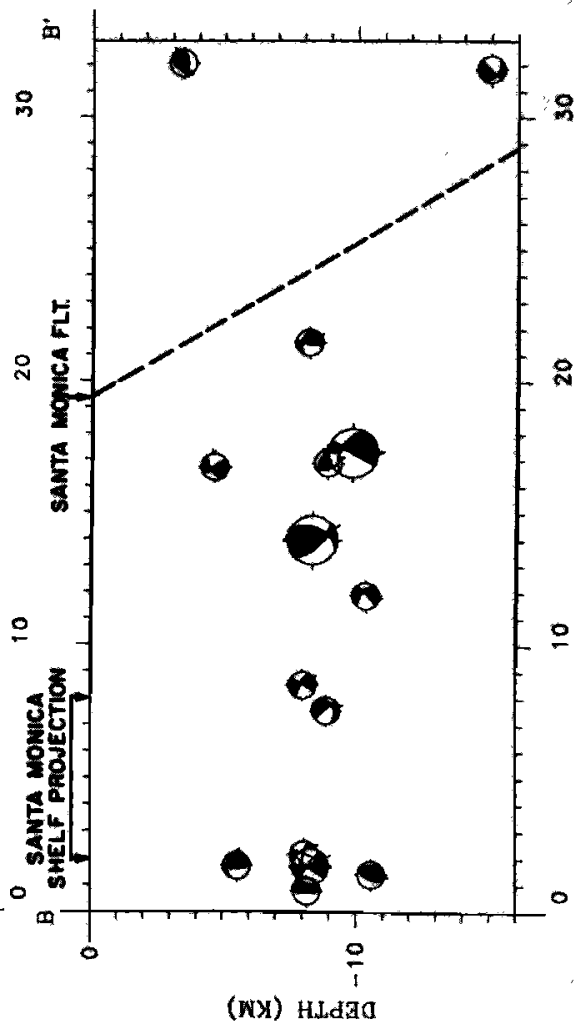

ชิ

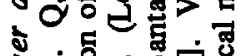
ङ.

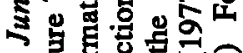

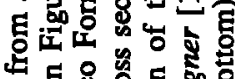
毛递客氮

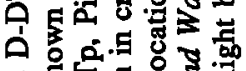

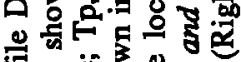

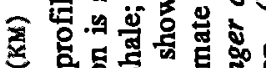

娄

论

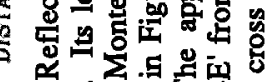
安运焉.5

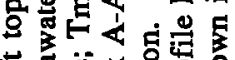

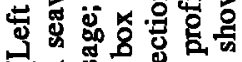

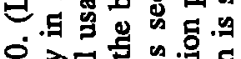

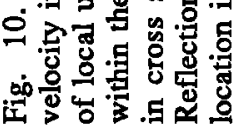




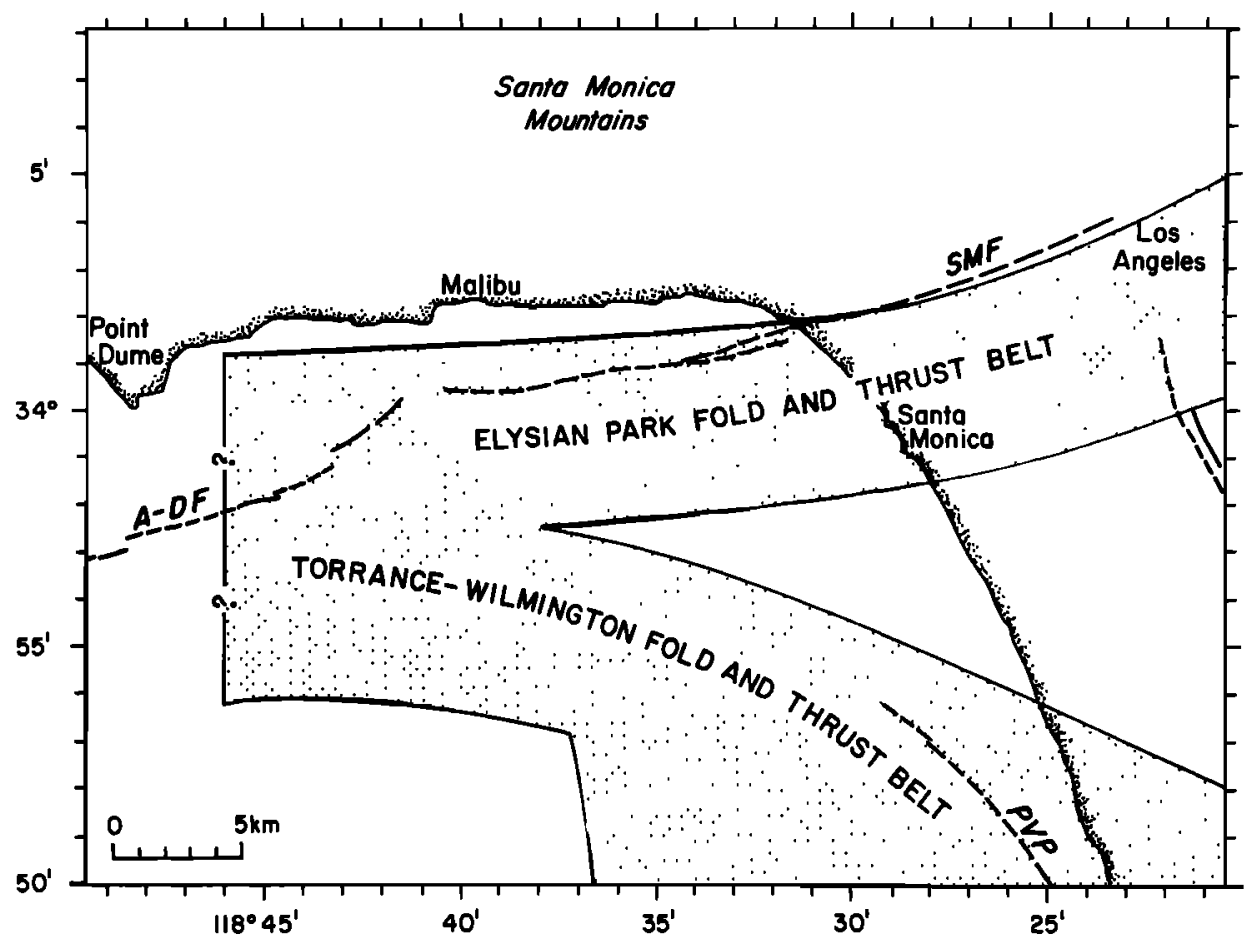

Fig. 11. A schematic illustration of the two fold and thrust belts that converge in Santa Monica Bay. The Elysian Park fold and thrust belt extends from Whittier along the northern flank of the Los Angeles basin into Santa Monica Bay. The TorranceWilmington fold and thrust belt extends along the western flank of the Los Angeles basin from the Dume embayment to the south of Long Beach.

\section{Conclusions}

The present tectonics in Santa Monica Bay are characterized by compression with folding near the surface and mostly thrust or reverse faulting earthquakes at depth. The transition from strike-slip faulting in the Peninsular Ranges to reverse faulting in the Transverse Ranges is accomplished through movement on thrust faults at depth. These previously unrecognized thrust faults contribute to seismic hazards in Los Angeles and the southern California coastal zone in terms of their potential for producing strong ground motion and small tsunamis.

Acknowledgments. We thank William Ellsworth, Peter Malin, Ross Stein, Lucile Jones, and John McRaney for critical reviews of the manuscript. This research was supported by USGS grant 14-08-0001-G1328 and USGS cooperative agreement 14-08-0001-A0264.

\section{REFERENCES}

Bird, P., and R. W. Rosenstock, Kinematics of present crust and mantle flow in southern California, Geol. Soc. Am. Bull., 95, 946-957, 1984.

Campbell, R. H., and R. F. Yerkes, Cenozoic evolution of the Los Angeles basin area - Relation to plate tectonics, in Aspects of the Geologic History of the California Continental Borderland, edited by D. G. Howell, Los Angeles, Calif., pp. 541-558, Pacific Section, American Association of Petroleum Geologists, Misc. Publ. 24, 1976.

Davis T. L., J. Namson, and R. F. Yerkes, A cross section of the Los Angeles area: seismically active fold and thrust belt, the 1987 Whittier-Narrows earthquake, and earthquake hazard, J. Geophys. Res., this issue.
Clarke, S. H., Jr., H. G. Greene, and M. P. Kennedy, Identifying potentially active faults and unstable slopes offshore, Evaluating Earthquake Hazards in the Los Angeles Region: An Earth-Science Perspective, edited by J. I. Ziony, U.S.Geol. Surv. Prof. Pap. 1360, 347-374, 1985.

Hadley, D., and H. Kanamori, Recent seismicity in the San Fernando region and tectonics in the west-central Transverse Ranges, California, Bull. Seismol. Soc. Am., $68,1449-1457,1978$.

Harding, T. P., and A. C. Tuminas, Interpretation of footwall (lowside) fault traps sealed by reverse faults and convergent wrench faults, Am. Assoc. Pet. Geol. Bull., 72, 738-757, 1988.

Hauksson, E., Seismotectonics of the Newport-Inglewood fault zone in the Los Angeles basin, southern California, Bull. Seismol. Soc. Am., 77, 539-561, 1987.

Hauksson, E., and L. M. Jones. The 1987 Whittier Narrows earthquake sequence in Los Angeles, southem California: Seismological and tectonic analysis, J. Geophys. Res., this issue.

Hauksson, E., and G. V. Saldivar, The 1930 Santa Monica and the 1979 Malibu, California, earthquakes, Bull. Seismol. Soc. Am., 76, 1542-1559, 1986.

Hauksson, E., et al., The 1987 Whittier Narrows earthquake in the Los Angeles metropolitan area, California, Science, 239, 1409-1412, 1988.

Heaton, T. H., The 1971 San Fernando earthquake: A double event? , Bull. Seismol. Soc. Am., 72, 2037-2062, 1982.

Humphreys, E., R. W. Clayton, and B. H. Hager, A tomographic image of mantle structure beneath southern California, Geophys. Res. Lett., 11, 625-627,1984.

Junger, A., and H. C. Wagner, Geology of the Santa Monica and San Pedro basins, California Continental Borderland, 
scale 1:250,000, U.S. Geol. Surv. Misc. Field Stud. Map, $M F-820,5$ sheets, 1 pamphlet, 1977.

Kamerling, M. J., and B. P. Luyendyk, Tectonic rotations of the Santa Monica Mountains region, western Transverse Ranges, California, suggested by paleomagnetic vectors, Geol. Soc. Am. Bull., 90, 331-337, 1979.

Klein, F. W., User's guide to HYPOINVERSE, a program for VAX and PC350 computers to solve for earthquake locations, U.S. Geol. Surv. Open File Rep., 85-515, 24 pp., 1985.

Lin, J., and R. Stein, Coseismic folding, earthquake recurrence, and the 1987 source mechanism at Whittier Narrows, Los Angeles basin, California J. Geophys. Res., this issue.

McCulloch, D.S., Evaluating tsunami potential, Evaluating Earthquake Hazards in the Los Angeles Region: An EarthScience Perspective, edited by J. I. Ziony, U.S. Geol. Surv. Prof. Pap. 1360, 375-414, 1985.

Michael, A. J., Determination of stress from slip data: Faults and folds, J. Geophys. Res., 89, 11,517-11,526, 1984.

Michael, A. J., Use of focal mechanisms to determine stress: A control study, J. Geophys. Res., 92, 357-368, 1987.

Namson, J., and T. Davis, A structural transect of the western Transverse Ranges, California: Implications for lithosphere kinematics and seismic risk evaluation, Geology, 16, 675-679, 1988.

Nardin, T. R., Late Cenozoic history of the Santa Monica Bay area, M.S. thesis, 117 pp., Univ. of South. Calif., Los Angeles, 1976.

Nardin, T. R., and T. L. Henyey, Pliocene-Pleistocene diastrophism of Santa Monica and San Pedro shelves, California continental borderland, Am. Assoc. Pet. Geol. Bull., 62, 247-272, 1978.

Norris, R., C. E. Johnson, L. M. Jones, and L. K. Hutton, The bulletin of the southern California seismic network (January-June, 1985), U.S. Geol. Surv. Open-File Rep., 86-96, 32 pp., 1986.

Pechmann, J. C., Tectonic implications of small earthquakes. The Central Transverse Ranges, in Recent Reverse Faulting in the Transverse Ranges, Califomia, edited by D. M. Morton and R. F. Yerkes, U.S. Geol. Surv. Prof. Pap. 1339, 97-112, 1987.

Reasenberg, P., and D. Oppenheimer, FPFTT, FPPLOT, and FPPAGE: Fortran computer programs for calculating and displaying earthquake fault-plane solutions, U.S. Geol. Surv. Open-File Rep., 85-739, 46 pp., 1985.
Roecker, S., and W. L. Ellsworth, VELEST, Fortran Program, U.S. Geol. Surv., Menlo Park, Calif., 1978.

Saldivar, G. V., Seismotectonics of the Santa Monica and Palos Verdes fault systems in the Santa Monica Bay, southern California, M.S thesis, 90pp., Univ. of South. Calif., Los Angeles, 1987.

Sheffels, B., and M. McNutt, Role of subsurface loads and regional compensation in the isostatic balance of the Transverse Ranges, California: Evidence for intracontinental subduction, J. Geophys. Res., 91, 64196431, 1986.

Vedder, J. G., L. A. Beyer, A. Junger, G. W. Moore, A. E. Roberts, J. C. Taylor, and H. C. Wagner, Preliminary report on the geology of the Continental Borderland of southem Califomia, U.S. Geol. Surv. Misc. Field Stud. Map, MF-624, 1974.

Webb, T. H., and H. Kanamori, Earthquake focal mechanisms in the eastern Transverse Ranges and San Emigdio Mountains, southern California and evidence for a regional decollement, Bull. Seismol. Soc. Am., 75, 737 757, 1985.

Yerkes, R. F., Geologic and seismologic setting, Evaluating Earthquake Hazards in the Los Angeles Region: An EarthScience Perspective, edited by J. I. Ziony, U.S. Geol. Surv. Prof. Pap., 1360, 347-374, 1985.

Yerkes., R. F., T. H. McCulloh, J. E. Schoellhamer, and J. G. Vedder, Geology of the Los Angeles basin, Califomia: An introduction, U.S. Geol. Surv. Prof. Pap., 420-A, 57 pp., 1965.

Ziony, J. I., and R. F. Yerkes, Evaluating earthquake and surface-faulting potential, Evaluating Earthquake Hazards in the Los Angeles Region: An Earth-Science Perspective, edited by J. I. Ziony, U.S. Geol. Surv. Prof. Pap., 1360, 43-91, 1985.

Ziony, J. I., C. M. Wentworth, J. M. Buchanan-Banks, and H. C. Wagner, Preliminary map showing recency of faulting in coastal southern California, U.S. Geol. Surv. Misc. Field Stud. Map, MF-585, 7 pp., 1974.

E. Hauksson and G. V. Saldivar, Department of Geological Sciences, MC 0740, University of Southem Califomia, Los Angeles, CA 90089-0740.

(Received September 14, 1988; revised January 11, 1989; accepted January 18, 1989) 